\title{
Geopolitical Strategy for the Territorialism of Oceans and Seas
}

\author{
Etiene Villela Marroni ${ }^{1}$, Milton L. Asmus ${ }^{2}$ \\ ${ }^{1}$ Laboratory of International Policy and Management of Oceanic Spaces, GIS Technology, \\ Federal University of Pelotas, Pelotas, Brazil \\ ${ }^{2}$ Institute of Oceanography, Federal University of Rio Grande, Rio Grande, Brazil \\ Email: etivm@terra.com.br, docasmus@furg.br
}

Received June 23, 2013; revised July 26, 2013; accepted August 17, 2013

Copyright (c) 2013 Etiene Villela Marroni, Milton L. Asmus. This is an open access article distributed under the Creative Commons Attribution License, which permits unrestricted use, distribution, and reproduction in any medium, provided the original work is properly cited.

\begin{abstract}
In the current international economic situation, the oceans and seas started to play a key role in the geopolitical balance of power between the coastal States. This article explores the concept of geopolitics, establishing a discussed relationship between such a concept and the considerations of coastal State and their territorialism policies. The concept of geopolitics cannot be simply understood as a condition of the position of a state in the international arena or its territorial ambition. The novel global ocean concept encompasses economic conditions facing the systemic combination of contemporary forces. Issues to be considered are maybe beyond the Convention on International Law of the Sea scenario in a dynamic economic and political international ocean.
\end{abstract}

Keywords: Geopolitics; Coastal States; Territorialization

\section{Introduction}

Since the dawn of human civilization, the ocean has been a subject of disputes and armed conflicts among several nations. In the past centuries, when the international trade of goods was affected by ocean navigation, there was a need for a regulation that would privilege the use of sea space and its resources.

The geopolitical agenda, the economic and political significance of mineral resources and the strategic direction of the power have changed over time, influenced by national and international relations and by the reflections of the economy and world politics. However, to use the global economic system as a vector for a new geopolitical arising from oceans and seas, we need to understand the term "world-economy", introduced by Fernand Braudel [1] from the German word Weltwirtschaft, which means the economy of just one portion of our planet. This author understands "the world-economy" as the one that covers the totality, the "market of the whole universe". However, he points out that the economy of only a portion of our planet can form an entire economy.

Indeed, following the conception of Braudel and using that as a metaphor for a study comprising a geoeconomics and the geopolitics for resources of the oceans and seas, we can assume that to deal with the movement of territorialism of continental shelf by coastal States around the globe would be the same that to study only a "portion" of the entire liquid mass of the planet.

Therefore, when referring the resources obtained through the process of territorial expansion of coastal States, we may be alluding to a kind of "world-economy" of the oceans, treating only a portion of the whole economic and considering the economic valuation of natural resources arising from this vast ecosystem.

Therefore, it is important to understand the reasons of the ocean expansionism carried out by coastal States.

\section{Understanding the Expansionism of Coastal States}

In the late seventeenth century, coastal States had a maritime sovereignty of three nautical miles from the coastline. This demarcation was stipulated as the distance that a cannon on land, could hit a target at sea. The maritime sovereignty of three nautical miles from the coastline continued until the 1940s.

Important technological developments and the needs generated by the Second World War caused the sea to pass to be considered from a new angle. Until then it had 
been essential the concern in dominating the "over" sea, seeking to protect the right of navigation and fishing. Since 1945 , it is added to this tendency the possibility and/or necessity of domination of the "down" sea, i.e., claims on the seabed, its soil and subsoil [2].

By the year 1945 it was thought that, beyond three miles, all countries could exploit resources through their fleet (mainly fish resources). With the end of World War II and as a result of it, the instability of resources and the ocean strategic potentialities (including underwater ones) has led several countries to widen their area of jurisdiction. The old notion that the ocean resources were inexhaustible began to be put into practice. In 1930, at the Hague Conference, the theme regarding the breadth of the territorial sea was approached, confirming the expansionary trend, but without reaching any agreement. Coastal States sought its sovereignty, a relevant factor for territorial defense, sometimes through bilateral or by unilateral action. In the Hague Conference of 1930, the object of study of the joint committee focused on territorial waters, with arguments that the territorial sea was part of the State territory, with the coastal States exercising sovereignty over its overlying space, allowing the innocent passage of foreign ships in the territorial sea. Later, in 1952, the Declaration of Santiago, Chile, Peru and Ecuador claimed exclusive sovereignty and jurisdiction up to 200 nautical miles [3,4].

The movement of "territorialization" was unfolding from the insurgent postwar power, United States, especially after the Statement by President Truman on September 28, 1945, when he said that the control over the natural resources of the continental shelf of your country belonged to its territory.

The Proclamation of the U.S. President, Harry Truman, announcing on September 28, 1945, the rights of the "jurisdiction and control" of the United States of America on the Continental Shelf, was an event not only marked an era in the history of Public International Law, but served as a warning signal to all countries of the world that had not yet considered properly the importance and the geo-economic, legal, political and strategic meaning of the extension of their lands, either continental or insular, in the direction the ocean depths, i.e., in the underwater areas [5].

Generally, the theories and concepts of limits are focused on land borders. This is nothing new considering that, in the course of history, territorial disputes between States occurred mostly on land. However, in the years after the Second World War, a considerable part of the globe territorial fluctuations happened much more in the oceans than on the continents, a result of increasing claims of territorial waters, where are located the continental shelves and Exclusive Economic Zones (EEZ) of coastal States.
According to Sanger [6], competition for the exclusive control of the ocean areas in the current period has been compared to the competition for colonies of European countries in the eighteenth and nineteenth century. Undoubtedly, this phenomenon led major initiatives such as the significant interest in the study of the oceans in relation to economics and geopolitics in the international context. Cohen [7] observes that the United States regretted the fact that two-fifths of the area of the world ocean form jurisdiction limits of coastal States as a result of the proliferation of Exclusive Economic Zones, occurred in the 1970s. So, maritime borders started receiving growing attention, due to the natural resources that can be found in them. The author comments two reasons for which the oceans have become an arena of conflict and disputes between States: first, a significant increase in the amount of resources from the oceans, and second, the rapid spread of sovereign States to cover virtually all areas of the planet.

The late twentieth century, mainly from the mid-1970s, was marked by profound changes in the economy and global geopolitics. All these transformations - that manifest beyond the field of economics and geopolitics, reflecting on the ideological and cultural aspects-had its counterpart in the theoretical field of International Political Economy, marked by the contribution of new theoretical perspectives focused on the discussion of the mode of operation and dynamics of the world system. Among these analyzes, and also from them, new contributions have consolidated into different views about the observed changes in the world economy and geopolitics [8].

\section{Geopolitical Strategy and the Territorialization Movement}

José L. Fiori [9] reiterates that the authors of the various theoretical and ideological trends seem to agree on a common diagnosis about the death of borders. This hypothesis, however, remains in a State of greater inaccuracy than the globalization one, and sometimes seems to be an echo of the same recurring and complementary utopia on depoliticized and borderless economies. This brings us to the fact that a new territorial and "imperialist" context, in relation to oceanic boundaries of coastal States. It is not only a matter of safeguarding borders delineated in multilateral agreements, but to expand those boundaries in order to "accumulate" territories rich in natural resources. The globalization movement, observed from this point of view, can become a new movement of territorialization, coming from the boundaries of the deep oceans. Such context well demonstrates that there is no "death" in the ocean boundaries, but a kind of "resurrection" of goods not explored in "deep worlds". With globalization, it becomes more evident. 
Therefore, it can be assumed that the increasing use of ocean resources is the result of a global phenomenon, where the States and their populations increasingly seek more, a high standard of living, increasing substantially the consumption of energy resources from continental shelves. While this argument appears clear, it is far from comprehensive and relevant related to the territorial behavior of the ocean geopolitics. However, it shows that, despite the fact that the States are looking for submarines energy resources, aiming at energy security, there is also a whole set of accumulation of capital through dividends that natural oceanic resources represent.

Giovanni Arrighi [10] demonstrates concern about changes in the spatial configuration of the processes of capital accumulation, which occurred in the 1970s. He says that this trend was prevalent mainly in countries and regions with high income to low income ones. The author says that, regardless of the direction of movement, since the 1970s the trend is increasing geographical mobility of capital. For this reason, the focus of this study is directed to the primacy and interest of nations to expand their ocean borders from the movement of territorialization, occurred in the 1970s.

In this sense, the choice of a geopolitical perspective is supported by two assumptions. The first believes that the resources from the oceans are more than just a legal phenomenon in the context of the expansionism dispute of continental shelves, in international organizations. Moreover, it represents a geopolitical phenomenon, in a way of territorial behavior driven by the geographical and political goals. The second assumes that the interest in ocean issues leads us, from the study of geopolitics, to a new geographical policy towards territorial symbolism, naval movements and natural resources. Thus, it is considered as a geopolitical movement facing the oceans. The emergence of a foreign interest in geopolitical strategic themes is the result of a recent redirection of the International System. When geopolitically, individuals are influenced to assume positions of national leadership and govern through geopolitical strategies and projects, then the geopolitics may provide an explanation, quite consistent, for national development schemes, territorial integration and relations with neighbors States.

According to studies by Parker [11], the geopolitical thinking was discredited after the Second World War, because of its association with the pseudoscience of the Nazis, called “Geopolitik”. But in the late 1960s geopolitics reborn, to the extent that international history has shown that States need a global interdependence to survive. The author explains that there is a variety of definitions of geopolitics, because since it became popularized in the 1960s, has been used in different contexts, thus hindering a clear understanding of their disciplinary nature. For purposes of scientific studies, geopolitics means the traditional reproduction of the balance of political power, in line with the geography and territoriality as a justification of diplomatic actions (or not) of States. In short, it is a way to stop the diplomacy and/or war through political power, in a context where politics, geography and history go together.

As the authors consulted, there is not a suitable model for geopolitical ocean. A model must have clearly defined concepts and rigorously tested theories for foreign policy analysis and international events. As a central feature, the geopolitical close focuses the geographical dimension of the policies of a State. Robert McColl [12] sees it as a concept perfectly legitimate and useful and simply refers to geographical factors behind policy decisions, directing attention to the spatial behavior of States.

This study is premised on the idea that the political interests of States must consider a spatial expression. Thus, international events, such as the issue of regionalism, disputes over natural resources, the formation of alliances and seeking access to the sea, become important issues for geopolitical research. Finally, the geopolitical contributions draw attention to the perceptions of politicians and how they respond to the surrounding environment. Not all initiatives aimed at foreign policy relate to the geography of the country, but usually the most important used to be. Americans absorbed their geopolitical doctrines intensively, relying on the "Monroe Doctrine". As a result, the Soviets and the Chinese were, at various times, convinced by the "imperialist-capitalist approach".

Susan Strange [13] foresaw, in their studies, that the uneven pace of change in the political and economic system affecting international relations between States would increase the global economic interdependence, driven by the acceleration in the development of nations. In this case, the "race for natural resources" is part of an immense geopolitical process of global economic system, which needs these "resources" in order to continue providing its positive feedback.

Thus, geopolitics has provided viable concepts of an organization to deal with a set of geographic variables and policies that influence the maritime dimension of foreign policy of coastal States. The maritime territorial policy needs to consider geographic factors, such as border and resources. The boundaries, for example, have become a topic of interest to scholars in geopolitics, as in principle, the boundary of a given State is a synthesized political and geographical fact. The border is a reference that establishes the territorial sovereignty of a State.

Studies by Spykman [14] State that borders are not only a line of demarcation. Also, and most importantly, are points of agreement structures of territorial power. The position of a board line can become an index to the power relations of the contending forces. The author observed three pre-conditions which a State must have to 
become a great power: the space, the internal coherence and freedom of movement. Preconditions, he said, for an expansion into the territorial ocean.

However, the maritime boundary does not constitute a prerequisite for the establishment of power in the International System. An example of this is the contemporary Japan, which reached status as an economic superpower, without changing their boundaries. It must be clear that power relations are not always depend on territorial relations.

Another concept that must be clarified is the "territoriality", which implies the property of jurisdiction of a State. This concept was introduced to describe the space occupied by the countries where they manage their population and natural resources. The territoriality thus implies the control of a particular geographic area, where the competition for natural resources is its driving force.

\section{Final Remarks}

In this conceptual synthesis, it becomes evident that the study of geopolitics is oriented to the interaction of geographical and political phenomena. Therefore, its understanding is also of utmost importance in order to understand the recent issue of global governance of the oceans. It is important that the "new" ocean geopolitics has as its main focus the various historical and geopolitical factors that form the basis of the interests of coastal States to the expansionism of their maritime territories. It is necessary to consider the studies focused on the geopolitics of seas and oceans, because they are able to elucidate the reason of coastal States seek, increasingly, to extend their territories overseas. It is noted that control over ocean space, in different countries, has been associated with a variety of themes, highlighting the national prestige, regional aspirations and strategic concerns of access to natural resources arising from Exclusive Economic Zones.

The understanding of concepts related to ocean and coastal environment, in line with the guidelines established by the United Nations Convention on the Law of the Sea, leads us to believe that the study of historical treaties linked to the ocean ecosystem is essential for understanding policy directed to him as well as the geographical area under consideration.

As a new "gold run", the expansion of ocean territories appears as a complicated reality in the international context, arising old quarrels that had already been overcome in the recent past (as the current Russia and the United States of America competition for submarine resources in the Arctic).

The oceans belong to those who retain the maritime technology and naval power. This defensive-nationalist posture can even be compared, in many respects, to the nexus of "realism" in the literature of international rela- tions, because there is certain logic on the absolute gain associated with the States. However, the geopolitics of the oceans is not new, as many civilizations have already used the immense continental waters for their sustenance, where also happened ethnic conflicts or discoveries of land. And, in this case, one cannot forget to thank Christopher Columbus or, before, Amerigo Vespucci.

\section{REFERENCES}

[1] F. Braudel, “A Dinâmica do Capitalismo,” Rocco, Rio de Janeiro, 1987.

[2] L. Albuquerque and J. Nascimento, “Os Princípios da Convenção das Nações Unidas sobre o Direito do Mar de 1982,” Revista Sequência, Vol. 23, No. 44, 2002.

[3] A. M. Mattos, “The New Law of the Sea,” Renovar, Rio de Janeiro, 1996.

[4] R. Sack, “Territorial Bases of Power,” In: B. Taylor, Ed., Political Studies from Spatial Perspectives, John Wiley \& Sons, Toronto, 1981.

[5] R. N. L. de Castro, "Fundamental Aspects of the Doctrine on Brazilian Continental Shelf," Brazilian Journal of International Politics, Vol. 12, No. 47/48, 1969.

[6] C. Sanger, "Ordering the Oceans: The Making of the Law of the Sea,” Zed Books, London, 1987.

[7] S. Cohen. "Geography and Politics in a World Divided," Oxford University Press, New York, 1973.

[8] V. L. Ribeiro, "The Political Economy of World-Systems and System Profiler Interstate Capitalist: A Comparative Analysis,” Graduate Program in Economics, UFSC, IV Brazilian Colloquium on the Political Economy of WorldSystems, 2010.

http://www.gpepsm.ufsc.br/html/arquivos/a_economia_p olitica_dos_sistemas-mundo_e_a_visao_do_sistema_inter estatal_capitalista.pdf

[9] J. L. F. Globalização, “Globalization, Hegemony and Empire,” In: M. C. Tavares and J. L. Fiori, Eds., Power and Money: A Political Economy of Globalization, Vozes, Rio de Janeiro, 1997.

[10] G. Arrighi, "The Long Twentieth Century: Money, Power and the Origins of Our Time,” Vera Ribeiro Unesp, São Paulo, 1996.

[11] G. Parker, "Western Geopolitical Thought in the Twentieth Century,” Croom Helm, London, 1985.

[12] R. McColl, "A Geopolitical Model for International Behaviour,” In: N. Kliot and S. Watermam, Eds., Pluralism and Political Geography, Croom \& Helm, London, 1983, pp. 173-186.

[13] S. Strange, "International Economics and International Relations: A Case of Mutual Neglect," International Affairs, Vol. 46, No. 2, 1970, pp. 304-315. doi:10.2307/2613829

[14] N. Spykman, "The Geography of the Peace," Archon Books, North Haven, 1969. 